LBC 349.42

\title{
ON COMPENSATION FOR DAMAGE CAUSED BY BEES: DISCUSSION QUESTIONS
}

\author{
Aleksey P. Anisimov \\ Volgograd Institute of Management - Branch of the Russian Presidential Academy of National Economy \\ and Public Administration, Volgograd, Russian Federation
}

Introduction. The article is devoted to the identification of the problems related to the legal regulation of beekeeping and compensation for personal injury caused by bees, since the legal problems of beekeeping have not yet become the subject of special research of legal scientists. For this purpose, the author studies the judicial practice related to harming the life and health of citizens, as well as the experience of a number of foreign countries. By using the methods of scientific cognition, first of all, the method of system analysis, it is found that it will be quite reasonable to establish in the sanitary legislation a direct ban on keeping apiaries in cities, which will reduce the intensity of "neighbor disputes" and will create additional guarantees for the realization of the right to a favorable environment. Results. First, currently the formation of judicial practice, connected with harm to owners of bees as species of domestic animals caused by pesticide use, without alerting the owners of apiaries, is in full swing in the Russian Federation, and, second, personal injury claims for compensation for damage caused by bees as sources of danger to health and property of citizens are increasingly heard in the courts of law. Conclusions. At the moment the norms scattered on a set of legal acts cannot consider all features of beekeeping as a type of activity, specifics of bees as living beings and a special type of property. The rights and responsibilities of the beekeeper as the owner of bees and the subject of agricultural production, requirements for placing and keeping apiaries, special aspects of the state control (supervision) in the field of beekeeping - all these issues must be resolved by a special federal law.

Key words: bees, harm, damage, law, pesticides, health, source of increased danger, court.

ББК 67.304 .1

УДК 349.42

\section{О ВОЗМЕЩЕНИИ ВРЕДА, ПРИЧИНЕННОГО ПЧЕЛАМИ: ДИСКУССИОННЫЕ ВОПРОСЫ}

\author{
Алексей Павлович Анисимов \\ Волгоградский институт управления - филиал Российской академии народного хозяйства \\ и государственной службы при Президенте РФ, г. Волгоград, Российская Федерация
}

Введение. Статья посвящена выявлению проблем, связанных с правовым регулированием пчеловодства и возмещения вреда жизни и здоровью граждан, причиненного пчелами, поскольку правовые проблемы пчеловодства до настоящего времени еще не стали предметом специальных исследований ученых-юристов. С этой целью автор изучает судебную практику, связанную с причинением вреда жизни и здоровью граждан, а также опыт ряда зарубежных стран. С помощью методов научного познания, прежде всего, метода системноанализа, установлено, что будет вполне обоснованным установление в санитарном законодательстве прямого запрета на содержание пасек в городах, что позволит снизить накал «соседских споров» и создать дополнительные гарантии реализации права на благоприятную окружающую среду. Результаты. В настоящий момент в Российской Федерации полным ходом идет формирование судебной практики, связанной, во-первых, с причинением вреда собственникам пчел как разновидности домашних животных, вызванных использованием пестицидов без оповещения владельцев пасек, и, во-вторых, все чаще в судебном порядке начинают рассматсся иски о возмешении вреда, причиненного пчелами как источниками повышенной опасности здоро() вью и имуществу граждан. Выводы. В настоящий момент разбросанные по множеству правовых актов 
нормы не могут учесть всех особенностей пчеловодства как вида деятельности, специфику пчел как живых существ и особого вида имущества. Права и обязанности пчеловода как собственника пчел и субъекта аграрного производства, требования к размещению и содержанию пасек, особенности государственного контроля (надзора) в области пчеловодства - все эти вопросы должны быть урегулированы специальным федеральным законом.

Ключевые слова: пчелы, вред, ущерб, закон, пестициды, здоровье, источник повышенной опасности, суд.

\section{Введение}

Правовые проблемы пчеловодства до настоящего времени еще не стали предметом специальных исследований ученых-юристов. Как следует из одного известного словаря, пчела - это «жалящее летающее перепончатокрылое общественное насекомое, перерабатывающее нектар в мед» [9]. Развитие пчеловодства жизненно необходимо для любого современного государства.

В отличие от других домашних животных (коров, свиней, овец и т. д.), требующих специальных кормов, для пчел нет необходимости в ежедневном подкорме. Кроме того, они не топчут посевы, а, наоборот, опыляют луга, способствуя развитию сельского хозяйства. С каждого гектара лугов и полей при грамотном подходе к делу можно получать не только овощи или зерно, но и мед, воск, пергу и иные продукты пчеловодства. Уровень развития пчеловодства характеризует уровень культуры сельскохозяйственного производства любой страны, и потому оно требует государственной поддержки, так как содействует обеспечению продовольственной безопасности государства.

Именно поэтому нормы о пчеловодстве мы встречаем во всех памятниках российского права, начиная еще с «Русской правды». Например, в Соборном уложении 1649 г. содержались статьи, регулирующие привлечение к ответственности за умышленные поджоги или иную порчу «бортных деревьев», повлекшие гибель пчел, их кражу, вопросы приобретения на пчел права собственности «завладевшим лицом» (гл. 10, ст. 21 8, 223, 239, 285) [11, c. 128-144].

\section{Основная часть}

Современное федеральное аграрное законодательство не содержит единого нормативного акта, который бы регламентировал пчеловодство. Вместе с тем, анализ положений Федерального закона «О личном подсобном хозяйстве», равно как и иных правовых актов, позволяет сделать вывод о том, что законодатель воспринимает пчел как разновидность домашних животных.

Именно поэтому ст. 6 данного закона упоминает право собственника земельного участка, предназначенного для ведения ЛПХ, разводить «сельскохозяйственных животных, пчел и птицу», приобретая на них право собственности. При этом, как отмечалось в научной литературе, органы государственной и местной власти «не вправе вмешиваться в деятельность граждан, ведущих личное подсобное хозяйство, и устанавливать какие-либо нормы (минимальные и максимальные) по количеству разрешенного поголовья скота, пчел и птицы, так как это не предусмотрено законодательством» [4, с. 138-139].

При этом, по мнению Р.Т. Бакировой, изначально товарными являются те ЛПХ граждан, которые занимаются, в том числе, пчеловодством [4, с. 31-32]. В свою очередь, В.В. Саскевич полагает, что согласно закону Республики Беларусь «О личных подсобных хозяйствах граждан», деятельность граждан, ведущих ЛПХ, и занимающихся производством, переработкой и реализацией производимой ими аграрной продукции не относится к предпринимательской деятельности. Вместе с тем отсутствие четкой регламентации подобной деятельности граждан (в том числе по производству, переработке и реализации произведенной ими продукции пчеловодства) является недостатком правового регулирования, требующим устранения. Это ограничивает возможности граждан по реализации излишков продукции пчеловодства, препятствует им в увеличении количества пчелосемей и развития пчеловодства в целом [12, с. 138-140].

К сожалению, на сегодняшний день ни один из федеральных законопроектов о пчеловодстве в России не был принят, и этот про- 
бел отчасти восполнен только в тех регионах, где приняты соответствующие законы субъектов РФ (Тюменская область, Ставропольский и Алтайский край и др.).

Несколько лучше обстоит дело в других странах СНГ (Казахстан, Беларусь, Украина и т. д.), где данный вопрос урегулирован более четко. Так, в Казахстане действует специальный закон «О пчеловодстве» от 12 марта 2002 г. № 303-II, регулирующий отношения в области «производства продуктов пчеловодства, охраны, использования и воспроизводства пчел, эффективного применения их для опыления сельскохозяйственных культур и всей опыляемой флоры, создания условий для повышения продуктивности пчеловодства, а также растениеводства, обеспечения гарантий соблюдения прав и интересов физических и юридических лиц, занимающихся пчеловодством» [7].

Наличие пробелов в правовом регулировании пчеловодства даже на уровне рамочных (общих) категорий влечет в России ряд практических проблем, связанных с возмещением вреда, во-первых, собственнику пчел как разновидности домашних животных, при их гибели из-за загрязненного состояния окружающей среды вследствие действий третьих лиц; во-вторых, вопросов возмещения вреда, причиненного здоровью граждан укусами пчел. В рамках первого аспекта проблемы в России принято несколько подзаконных актов, регламентирующих процедурные вопросы использования пестицидов и агрохимикатов на полях, от действия которых обычно и гибнут пчелы. Такая профилактика отравлений пчел предполагает, что владельцев пасек должны заблаговременно оповещать о дне предстоящей обработки полей химикатами, причем такую обработку следует проводить в утреннее или вечернее время (в условиях отсутствия пчел) и не в период цветения медоносов. Однако вопреки инструкциям, подобные отравления пчел не редкость.

1. Комаричский районный суд Брянской области установил, что химической авиационной обработкой садов была грубо нарушена технология, в том числе не были соблюдены границы санитарно-защитных зон, опыление производилось не в утренние и вечерние часы (как это положено), и в итоге отравле- ние пчел стало массовым. Несмотря на ряд искусственных трудностей, созданных истцам местной администрацией (например, в части выдачи документации о ядохимикатах), идентификация ядохимикатов была произведена Брянской областной контрольно-токсикологической экспертизой. В итоге ее расчеты материального ущерба истцам суд признал обоснованными.

Между тем, как отмечалось в научной литературе, до сих пор сохраняется ряд трудноразрешимых в судебной практике вопросов. Во-первых, размер вреда ограничивается убытками, выражающимися в гибели пчел; между тем, очевидно, что от ядохимикатов страдает и другая фауна - насекомые и иные представители животного мира; и как же тогда рассчитывать экологический ущерб от неправильного применения ядохимикатов в сельском хозяйстве?

Во-вторых, неясно какое воздействие оказывает периодическое использование ядохимикатов в аграрном секторе на здоровье человека? Едва ли такая деятельность не имеет последствий [6, с. 56-57]. Согласно ст. 79 Федерального закона «Об охране окружающей среды» от 10 января 2002 г. № 7-Ф3, вред, причиненный здоровью и имуществу граждан негативным воздействием окружающей среды в результате хозяйственной и иной деятельности юридических и физических лиц, подлежит возмещению в полном объеме. Эти вопросы также должны стать предметом рассмотрения в ходе судебных заседаний.

2. В Орловской области также отмечались случаи массовой гибели пчел из-за ядохимикатов. Так, в 2009 г. пасечники из Кромского района обратились в службу ветеринарного и фитосанитарного контроля с жалобой на внезапную гибель 47 пчелосемей (а это более трех миллионов пчел). Экспертиза установила, что пчелы погибли от пестицидов, которыми один из фермеров обработал посевы гороха (ульи располагались в 600 метрах от поля). Поскольку фермер не предупредил ветеринарную службу и пасечников, в отношении него было возбуждено уголовное дело по факту нарушения ветеринарных правил, установленных для борьбы с болезнями и вредителями растений, повлекшего по неосторожности тяжкие последствия (ст. 249 УК РФ) [3]. 
3. Группа граждан обратились в суд с иском к Обществу с ограниченной ответственностью Агрофирма «Башкирский лимузин» о возмещении материального ущерба. В обоснование иска они указали, что являются владельцами пасек, расположенных на лесных участках площадью 0,05 га в Куюргазинском участковом лесничестве. Как следует из ветеринарной справки от 13 июня 2015 г., данные пасеки подверглись исследованию на инфекционные и инвазионные заболевания. Участок, где располагаются пасеки истцов, граничит с полем, находящимся в пользовании ООО «Башкирский лимузин». Данное ООО 14 июня 2015 г. без предупреждения обработало поле химикатами «Шанстар». В результате пчелы, находившиеся в тот момент в поле, погибли.

По обращению истцов Мелеузовским территориальным отделом государственного ветеринарного надзора была проведена проверка деятельности ООО. По ее итогам было выявлено административное правонарушение, предусмотренное ст. 21 Закона Республики Башкортостан «О пчеловодстве» от 20 июня 2011 года. «Башкирский лимузин» был привлечен к административной ответственности по ч. 5 ст. 7.1 Кодекса об административных правонарушениях Республики Башкортостан, так как в результате проведенной ООО химической обработки полей 14 июня 2015 г. погибло 50 \% пчел. Таким образом, было доказано причинение ООО истцам материального ущерба. В итоге суд принял решение о взыскании с ответчика причиненного им вреда [1].

4. Решением Суздальского районного суда Владимирской области от 7 августа 2002 г. был удовлетворен иск Владимирского природоохранного прокурора в интересах граждан-пчеловодов о взыскании с СХП «Нива» и Агрофирмы «Волгохрансгаз» возмещения вреда, связанного с гибелью пчел.

Суд установил, что причиной гибели пчел стало применение пестицидов средней и малой токсичности в большом количестве при механической обработке полей с целью уничтожения сорняков. Принимая решение о взыскании причиненного ущерба, суд сослался на ст. 1079 Гражданского кодекса РФ, квалифицируя действия ответчика как владельца источника повышенной опасности $[13$, с. $51-$
52]. На это ориентирует и п. 35 Постановления Пленума Верховного суда РФ «О применении судами законодательства об ответственности за нарушения в области охраны окружающей среды и природопользования» от 18.10.2012 № 21 (ред. от 26.05.2015), согласно которому, если вред причинен юридическими лицами и гражданами, деятельность которых связана с повышенной опасностью для окружающей среды, ответственность наступает независимо от наличия вины, если причинитель вреда не докажет, что вред возник вследствие непреодолимой силы или умысла потерпевшего.

5. При наличии определенных обстоятельств размер возмещения вреда пострадавшим пчеловодам может быть уменьшен. Так, граждане-пчеловоды обратились с иском в суд, где указали, что они вывезли свои пасеки в заброшенный сад у сельского поселения. Спустя несколько дней они обнаружили, что пчелы не попадают на прилетные доски, бьются о стенки ульев, ползают в траве и собираются в кучки. Они поняли, что пчелы отравлены, и вызвали на пасеку работников полиции и ветеринарного врача (он взял от каждого улья пробы погибших пчел). Далее на полях ответчика они обнаружили следы от обработки сельскохозяйственных культур пестицидами, и ветеринарным врачом были взяты пробы, отправленные затем в Воронежскую областную ветеринарную лабораторию. По итогам исследования данных образцов было установлено, что ответчик обработал посевы гороха и пшеницы пестицидами, которыми были отравлены и все пчелы. При этом ответчик объявления о предстоящей обработке полей пестицидами не давал, и пчеловодов об обработке, характере и зоне применения пестицидов не уведомлял.

Действия ответчика привели к гибели пчел и частично расплода. Однако решением Таловского районного суда Воронежской области от 12.03.2014 г. исковые требования были удовлетворены лишь частично. Суд указал, что ответчик произвел обработку пестицидами полей в непосредственной близости от сельского поселения, воздействие которых создает повышенную вероятность причинения вреда. Учитывая степень опасности этих препаратов, районный суд обоснованно 
пришел к выводу о том, что ответчик осуществлял деятельность, представлявшую повыиенную опасность для окружающих, а потому обязан возместить причиненный этой деятельностью вред.

Вместе с тем, размещение кочевой пасеки на чужом земельном участке должно осуществляться на основании договора, заключенного между собственником пасеки и правообладателем земельного участка; в целях предупреждения гибели пчел (пчелосемей), а также снижения урожайности и качества сельскохозяйственных культур, место размещения пасеки должно согласовываться пчеловодами со всеми физическими и юридическими лицами, применяющими пестициды при возделывании сельскохозяйственных культур на расстоянии 7 километров от предполагаемого размещения пасеки, с оформлением двустороннего соглашения о взаимодействии. Поскольку судом первой инстанции установлено, что никаких двусторонних соглашений с целью профилактики отравлений пчел пестицидами истец ни с кем не заключал, то, следовательно, он вывез свою стационарную пасеку на период медосбора на не принадлежащий ему земельный участок самовольно. Суд обоснованно усмотрел в действиях пчеловода грубую неосторожность и установил наличие вины ответчика - юридического лица в гибели пчел и причинении убытков, а также наличие вины истца как собственника пчел, допустившего размещение своей пасеки без какого-либо уведомления юридических лиц, применяющих пестициды, на не принадлежащем ему земельном участке. Согласно ст. 1983 ГК РФ, если грубая неосторожность самого потерпевшего способствовала возникновению или увеличению вреда, в зависимости от степени вины потерпевшего и причинителя вреда размер возмещения должен быть уменьшен. При этих обстоятельствах районный суд правомерно уменьшил размер возмещения вреда, пропорционально степени вины истца [2].

6. Далеко не во всех случаях гражданампчеловодам удается доказать факт причинения вреда и все необходимые причинно-следственные связи.

Так, 7 августа 2011 г. в результате авиационной химической обработки полей подсол- нечника, находящегося у ООО на праве аренды, у ряда граждан погибло несколько десятков пчелосемей. Данные граждане обратились в суд с иском к ООО о возмещении материального ущерба в связи с гибелью пчел.

В обоснование своих требований они указали, что пчелосемьи располагались на территории их частных домовладений, находящихся недалеко от поля, которым владеет ответчик. В результате рассмотрения дела, суд принял решение о частичном возмещении материального ущерба. Отменяя решение районного суда, Волгоградский областной суд указал, что в качестве документов, на которые ссылались истцы в подтверждение факта отравления пчел, были результаты экспертизы от 15.08.2011 г., а также акт ветеринарно-санитарного обследования от 09.08.2011 года. Результатом исследования явилось отсутствие в представленных образцах фосфорорганических пестицидов. Исследование на пиретроиды не производилось ввиду отсутствия в лаборатории материально-технического оснащения. Представитель ответчика в ходе судебного разбирательства пояснил, что обработка сельскохозяйственных угодий производилась препаратом, который относится к пиретроидным инсектицидам и используется для защиты сельскохозяйственных культур от комплекса вредителей. Однако исследование проб пчел, меда, полевых растений на пиретроиды не было произведено, а потому установить, что пчелосемьи истцов были отравлены по вине ООО при химической обработке полей подсолнечника не представляется возможным. Таким образом, причинно-следственная связь между помором 7 августа 2011 г. пчел и действиями ответчика по обработке сельскохозяйственных угодий в ходе судебного разбирательства не была установлена. Исходя из того, что факт вины ответчика в причинении ущерба и причинно-следственная связь между его действиями и причиненным истцам вредом не доказаны, судебная коллегия посчитала необходимым в удовлетворении исковых требований к ООО отказать [8].

Не менее актуальным является и вопрос о возмещении вреда, причиненного здоровью и имуществу граждан укусами пчел. Так, Л. была владелицей собаки, а ее сосед С. держал на своем приусадебном участке 
пчел. Л. обратилась в суд с иском к С. о возмещении вреда, связанного с гибелью ее собаки от укусов пчел. Решением Петушинского районного суда Владимирской области от 21 января 2000 г. иск был удовлетворен частично, причем суд признал пчел источником повышенной опасности. С этой позицией согласилась и судебная коллегия по гражданским делам Владимирского областного суда. Между тем, в научной литературе данное решение суда было подвергнуто критике. В частности отмечалось, что пчел нельзя считать источником повышенной опасности для окружающих, поскольку пчеловодство как вид деятельность вполне подконтрольна, а полезные свойства пчел всем известны.

В то же время для граждан, которые страдают аллергией (а их число весьма значительно) контакт с пчелами может повлечь трагические последствия. Как известно, в теории российского права большинство ученых не поддерживают идею о судебном прецеденте как источнике права. Однако законодатель ни в ГК РФ, ни в других законах не дает исчерпывающего перечня источников повышенной опасности, так как это просто невозможно сделать - с развитием науки и техники появление новых источников повышенной опасности неизбежно. Однако их примерный перечень в Гражданском кодексе РФ есть, то есть они достаточно определенны и даже конкретизированы. Но этот перечень все же примерный, поэтому судебный субъективизм неизбежен, поскольку в этой сфере сильно развит институт судебного усмотрения [13, c. 30-31].

Между тем, критическое отношение к возможности признания пчел источником повышенной опасности опровергается судебной практикой в РФ.

Представляется, что наибольшие проблемы пчелы создают в случаях, когда их разведением занимаются жители городов или крупных сельских населенных пунктов. Так, по решению президиума Омского областного суда, собственницу пасеки обязали демонтировать десять ульев, расположенных в центре города. Иск был предъявлен несколькими семьями, пострадавшими от укусов пчел. В своем решении суд подчеркнул, что осуществление прав и свобод человека не должно нарушать права и свободы других лиц, в том числе и на благоприятную окружающую среду. В результате на собственницу городской пасеки возложена обязанность демонтировать ульи в центре города, и перенести их в более подходящее для ведения пчеловодства место [5].

В другом аналогичном случае Тавдинский городской прокурор обратился в суд с иском в интересах неопределенного круга лиц к Е., где просил возложить на ответчика обязанность привести пасеку в соответствие с законодательством. В обоснование иска он указал, что по результатам проведения проверки пасеки Е. установлено, что последний в нарушение Федерального закона «О санитарно-эпидемиологическом благополучии населения», инструкции по содержанию пчелиных семей и организации пчеловодства не принимает меры по обеспечению безопасности находящихся поблизости людей, которые могут подвергнуться нападению пчел, чем нарушаются права граждан на безопасную окружающую среду и обеспечение благоприятных условий жизнедеятельности. Одновременно прокурором предъявлен иск и в интересах Н., подвергшейся укусам пчел, к Е., о взыскании в ее пользу компенсации морального вреда. Прокурор настаивал на требованиях обязать ответчика расположить улья с находящимися в них пчелосемьями на расстоянии не менее 3-5 метров от границ земельного участка, отделить жилища пчел с находящимися в них пчелосемьями сплошным забором по периметру земельного участка высотой не менее 2 метров, летки ульев направить к середине участка, взыскать с ответчика в пользу $\mathrm{H}$. компенсацию морального вреда. Н. заявленные требования поддержала, пояснив, что ее земельный участок граничит с земельным участком ответчика, на котором последний содержит пчел, в связи с чем (особенно, в последние три года) она испытывает значительные неудобства, так как не может пользоваться огородом, опасаясь укусов пчел, и, выходит на огород даже в жаркую погоду в одежде.

Е. заявленные требования не признал, указав, что в настоящее время его пасека полностью соответствует установленным требованиям. В результате рассмотрения данно- 
го дела исковые требования Тавдинского городского прокурора были удовлетворены частично. В апелляционной жалобе Е. указал, что суд неправильно установил фактические обстоятельства дела, настаивая на том, что из представленных документов не усматривается, что у Н. были укусы именно пчел, а не других насекомых (осы, мошка, оводы и др.). Кроме того, в округе имеются и другие пасеки, незарегистрированные в установленном порядке, поэтому отсутствуют достоверные доказательства о том, что пчелы, принадлежащие именно ему, покусали истца. Исследовав материалы дела, Судебная коллегия не нашла оснований к отмене решения суда. Суд правильно определил характер правоотношений и закон, подлежащий применению при разрешении спора, на основании которого верно определен круг обстоятельств, имеющих значение для дела, при этом нарушений норм материального или процессуального права судом не допущено [10].

\section{Заключение}

Подводя итоги, следует заметить, что в России полным ходом идет формирование судебной практики, связанной, во-первых, с причинением вреда собственникам пчел как разновидности домашних животных, вызванных использованием пестицидов без оповещения владельцев пасек. Во-вторых, все чаще в судебном порядке начинают рассматриваться иски о возмещении вреда, причиненного пчелами как источниками повышенной опасности здоровью и имуществу (например, в случае гибели собаки от укусов) граждан.

В настоящий момент разбросанные по множеству правовых актов нормы не могут учесть всех особенностей пчеловодства как вида деятельности, специфику пчел как живых существ и особого вида имущества. Права и обязанности пчеловода как собственника пчел и субъекта аграрного производства, требования к размещению и содержанию пасек, особенности государственного контроля (надзора) в области пчеловодства - все эти вопросы должны быть урегулированы специальным федеральным законом. Не менее важный аспект снижения остроты проблемы заключается в необходимости развития в России «органического земледелия», то есть сельскохозяйственного производства, в ходе которого не используются пестициды, и осуществляется производство экологически чистой продукции. Реализация такой стратегии, которая в настоящий момент с большим или меньшим успехом осуществляется в республиках бывшего СССР (в части в Украине и Беларуси), позволяет предположить, что уменьшение использования ядохимикатов устранит и саму угрозу для пчел.

Наконец, вполне обоснованным представляется установление в санитарном законодательстве прямого запрета на содержание пасек в городах, что позволит снизить накал «соседских споров» и позволит создать дополнительные гарантии реализации права на благоприятную окружающую среду.

\section{СПИСОК ЛИТЕРАТУРЫ}

1. Апелляционное определение Верховного суда Республики Башкортостан от 3 ноября 2015 г. по делу № 33-19289/2015. - Доступ из справ.-правовой системы «КонсультантПлюс» (дата обращения: 02.06.2017).

2. Апелляционное определение Воронежского областного суда от 29 мая 2014 г. № 33-2950. - Доступ из справ.-правовой системы «КонсультантПлюс» (дата обращения: 02.06.2017).

3. Арсеньев, П. В защиту пчел. Новый закон призван помочь развитию отрасли / П. Арсеньев // Российская газета. Экономика Центрального округа. - 2010. - 11 мая. - № 5178.

4. Бакирова, Р. Т. Правовой регулирование деятельности личных подсобных хозяйств : дис. ... канд. юрид. наук / Бакирова Рафиля Талгатовна. Оренбург, 2006. -209 с.

5. Граф, Н. Покусались из-за пчел. Владелицу пасеки привлекли к суду соседи / Н. Граф // Российская газета. - 2012. - 2 апреля. - № 5744.

6. Гузенко, В. Н. Соотношение убытков, причиненных природным ресурсам как мера гражданской ответственности : дис. ... канд. юрид. наук / Гузенко Валентина Николаевна. - Волгоград, 2007. - 205 с.

7. Закон Республики Казахстан от 12 марта 2002 г. № 303-II «О пчеловодстве» // Казахстанская правда. - 2002. - № 59.

8. Кассационное определение Волгоградского областного суда от 1 декабря 2011 г. по делу № 3314796/2011. - Доступ из справ.-правовой системы «КонсультантПлюс» (дата обращения: 03.06.2017).

9. Ожегов, С. И. Толковый словарь русского языка / С. И. Ожегов, Н. Ю. Шведова. - М., 1992. - 
Электрон. текстовые дан. - Режим доступа: http:// dic.academic.ru/dic.nsf/ogegova/194994 (дата обращения: 02.06.2017). - Загл. с экрана.

10. Определение Свердловского областного суда от 6 марта 2013 г. по делу № 33-2762/2013. Доступ из справ.-правовой системы «КонсультантПлюс» (дата обращения: 02.06.2017).

11. Памятники русского права. - М. : Госюриздат, 1957. Вып. 6. Соборное уложение царя Алексея Михайловича 1649 года / под ред. К. А. Софроненко. - С. 128-144.

12. Саскевич, В. В. Проблемы правового регулирования осуществления пчеловодства физическими лицами в Республике Беларусь / В. В. Саскевич // Актуальні проблеми правового регулювання аграрних, земельних, екологічних відносин і природокористування в Україні та країнах СНД : міжнар. наук.-практ. конф. (м. Луцьк, 10-11 вересня 2010 р.) : збірник наукових прац / за заг. ред. А.М. Статівки та ін. - Луцьк : РВВ ЛНТУ, 2010. - С. 138-140.

13. Шишкин, С. К. Возмещение вреда, причиненного источником повышенной опасности, по российскому гражданскому праву : дис. ... канд. юрид. наук / Шишкин Сергей Константинович. M., 2004. -195 c.

\section{REFERENCES}

1. Apellyatsionnoe Opredelenie Verkhovnogo Suda Respubliki Bashkortostan ot 3 noyabrya 2015 g. po delu № 33-19289/2015 [The Appeal Decision of the Supreme Court of the Republic of Bashkortostan of November 3, 2015 on Case no. 33-19289 / 2015]. Access from Reference Legal System "KonsultantPlyus" (accessed June 2, 2017).

2. Apellyatsionnoe Opredelenie Voronezhskogo oblastnogo Suda ot 29 maya 2014 g. № 33-2950 [The Appeal Decision of the Voronezh Regional Court of May 29, 2014 no. 33-2950]. Access from Reference Legal System "KonsultantPlyus" (accessed June 2, 2017).

3. Arsenyev P. V zashchitu pchel. Novyy zakon prizvan pomoch razvitiyu otrasli [In Defense of Bees. The New Law is Called on to Ensure the Development of the Industry]. Rossiyskaya gazeta. Ekonomika Tsentralnogo okruga, 2010, May 11, no. 5178.

4. Bakirova R.T. Pravovoy regulirovanie deyatelnosti lichnykh podsobnykh khozyaystv: dis. ... kand. yurid. nauk [Legal Regulation of the Private Economies' Activities. Cand. jurid. sci. diss.]. Orenburg, 2006. 209 p.

5. Graf N. Pokusalis iz-za pchel. Vladelitsu paseki privlekli k sudu sosedi [Bites Because of Bees. The
Owner of the Apiary Was Brought to Court by the Neighbors]. Rossiyskaya gazeta, 2012, April 2, no. 5744.

6. Guzenko V.N. Sootnoshenie ubytkov, prichinennykh prirodnym resursam kak mera grazhdanskoy otvetstvennosti: dis. ... kand. yurid. nauk [The Ratio of Losses Caused to Natural Resources as a Measure of Civil Liability. Cand. jurid. sci. diss.]. Volgograd, 2007. 205 p.

7. Zakon Respubliki Kazakhstan ot 12 marta $2002 \mathrm{~g}$. № 303-II «O pchelovodstve» [Law of the Republic of Kazakhstan of March 12, 2002 no. 303-II "On Beekeeping"]. Kazakhstanskaya Pravda, 2002, March 19, no. 59.

8. Kassatsionnoe opredelenie Volgogradskogo oblastnogo Suda ot 1 dekabrya 2011 g. po delu № 3314796/2011 [The Cassation Decision of the Volgograd Regional Court of December 1, 2011 on Case no. 3314796/2011]. Access from Reference Legal System "KonsultantPlyus" (accessed June 3, 2017).

9. Ozhegov S.I., Shvedova N.Yu. Tolkovyy slovar russkogo yazyka [Explanatory Dictionary of the Russian Language]. Moscow, 1992. URL: http:// dic.academic.ru/dic.nsf/ogegova/194994 (accessed June 2, 2017).

10. Opredelenie Sverdlovskogo oblastnogo Suda ot 6 marta 2013 g. po delu № 33-2762/2013 [The Decision of the Sverdlovsk Regional Court of March 6, 2013 on Case no. 33-2762/2013]. Access from Reference Legal System "KonsultantPlyus" (accessed June 2, 2017).

11. Pamyatniki russkogo prava. Vypusk 6. Sobornoe Ulozhenie tsarya Alekseya Mikhaylovicha $1649 \mathrm{~g}$. [The Monuments of Russian Law. Issue 6. Cathedral Code of the Tsar Aleksey Mikhailovich, 1649]. Moscow, 1957, pp. 128-144.

12. Saskevich V.V. Problemy pravovogo regulirovaniya osushchestvleniya pchelovodstva fizicheskimi litsami v Respublike Belarus [The Problems of Legal Regulation of Beekeeping by Individuals in the Republic of Belarus]. Stativki A.M., ed. Aktualni problemi pravovogo regulyuvannya agrarnikh, zemelnikh, ekologichnikh vidnosin $i$ prirodokoristuvannya v Ukraïni ta kraïnakh SND: mizhnar. nauk.-prakt. konf. (m. Lutsk, 10-11 veresnya 2010 r.): zbirnik naukovikh prats. Lutsk, RVV LNTU, 2010,pp. 138-140.

13. Shishkin S.K. Vozmeshchenie vreda, prichinennogo istochnikom povyshennoy opasnosti, po rossiyskomu grazhdanskomu pravu: dis. ... kand. yurid. nauk [Compensation for Harm Caused by a Source of Increased Danger, According to the Russian Civil Law]. Moscow, 2004. 195 p. 


\section{Information about the Author}

Aleksey P. Anisimov, Professor, Department of Constitutional and Administrative Law, Volgograd Institute of Management - Branch of the Russian Presidential Academy of National Economy and Public Administration, Gagarina St., 8, 400131 Volgograd, Russian Federation, anisimovap@mail.ru.

\section{Информация об авторе}

Алексей Павлович Анисимов, профессор кафедры конституционного и административного права, Волгоградский институт управления - филиал Российской академии народного хозяйства и государственной службы при Президенте РФ, ул. Гагарина, 8, 400131 г. Волгоград, Российская Федерация, anisimovap@mail.ru. 